Article

\title{
Creativity for Sustainability: How Do Polish Teachers Develop Students' Creativity Competence? Analysis of Research Results
}

\author{
Anna Mróz *(D) and Iwona Ocetkiewicz \\ Faculty of Pedagogy and Psychology, Pedagogical University of Cracow, 30-084 Cracow, Poland; \\ iwona.ocetkiewicz@up.krakow.pl \\ * Correspondence: anna.mroz@up.krakow.pl
}

Citation: Mróz, A.; Ocetkiewicz, I. Creativity for Sustainability: How Do Polish Teachers Develop Students' Creativity Competence? Analysis of Research Results. Sustainability 2021, 13, 571. https://doi.org/10.3390/ su13020571

Received: 25 November 2020 Accepted: 6 January 2021 Published: 9 January 2021

Publisher's Note: MDPI stays neutral with regard to jurisdictional clai$\mathrm{ms}$ in published maps and institutional affiliations.

Copyright: (C) 2021 by the authors. Licensee MDPI, Basel, Switzerland. This article is an open access article distributed under the terms and conditions of the Creative Commons Attribution (CC BY) license (https:// creativecommons.org/licenses/by/ $4.0 /)$.

\begin{abstract}
Called the competence of the 21st century, creativity is one of the key competencies for sustainable development. There is no fixed path to achieve sustainability and it is subject to human creativity. However, integrated development of both is surely an under-researched topic. Creative thinking and creative problem solving should be a necessary and significant component of modern sustainable education. Students must learn to associate creativity with sustainability. Helping them understand sustainability by exposing them to the sustainable development goals (SDGs) and designing new creations that honor the planetary boundaries is crucial. The paper focuses on developing creativity by Polish teachers who work with adolescents. The assumption was that creativity can be developed using certain didactic methods and forms. The objective of the study was to explore and to describe which didactic methods and forms teachers use to shape the competence of creativity in students. The teachers took part in a survey and were asked what methods and forms they use to develop creativity in their students. The sample consisted of 337 teachers from the Małopolska region. The results of the analyses show that teachers use only a few of the methods recommended to facilitate creativity, which may lead to a low level of this competence among the students. They also use the most common didactic forms, which may not support the development of creativity competences. Moreover, the research results show that there are several factors, such as the teacher's seniority and the location of the school, which determine the choice of individual teaching methods.
\end{abstract}

Keywords: education for sustainable development; key competence for sustainability; teaching methods; creativity; teaching for creativity

\section{Introduction}

Today, creativity is largely considered synonymous with success [1]. Some theories of intelligence treat creativity as one of the characteristics of the intellect [2], others see it much wider as an activity where, besides intellect, motivation, personality and other components are important [3]. One may say it is why in the 21st century the development of students creativity has become a significant teaching objective for school teachers [4]. Acquiring knowledge is no longer the only aim of schooling. The capacity to utilize knowledge and to produce new knowledge requires creativity. This is now one of the important skills that schools are meant to cultivate and increase in students [5]. Many countries have developed creative curricula to promote creativity development in their schools [6], but as Thi Bich Lieu Tran, Thi Nhat Ho, Sarah V. Mackenzie and Long Kim Le noted [4] and international research has found, teaching for creativity is challenging for a number of reasons. Tran et al. [4] found that lack of guidance for teachers in terms of how to prepare, implement and assess a lesson which aims to develop students' creativity and how to assess students' creativity were major challenges that limited successful teaching for creativity.

Changes which take place in the post-modern, globalized world and the challenges which modern people must face generate new tasks for education. The need to revise 
the existing role of school and educational challenges results from the real, revolutionary civilizational change humans are experiencing today. New global technologies change the labor market, forms of employment and communication and even identities. In the post-modern world, traditional methods of acquiring knowledge, communicating, working, managing or spending free time are insufficient-they undergo constant and rapid modifications which young people accept easily, generating at the same time the next, new changes. The term change, like new model, is symptomatic to what is happening in the global village of the 21st century. It is clear that schools face hitherto unknown challenges. The development of information and communication technologies has expanded the scope of possible personal interactions and provided attractive communication tools which enable creating and maintaining new contacts regardless of geographical and time limitations [7]. Given these changes, the traditional education model has also been disintegrating. Many researchers who have referred to the post-modern approaches conclude that in its present form, education is based on the patterns and ideas from the past eras, consistent with the social needs and axioms valid in the past. The crisis of education results from the crisis of institutions which were established and prepared to respond to the needs of another-long gone-reality based on legitimization, a clearly defined formula of power and a precise, fundamental set of values [8]. This imposes new requirements to the personality of the teacher and his or her pedagogical activity [9].

The post-modern school should, first of all, stop consolidating the model of knowledge understood as a constantly growing information set. This model worked in the industrial society when the information resources were limited in size, stable and not widely available. Today, in order to narrow the cultural gap among young people, we need an education model in which knowledge is defined as a rich set of procedures to deal with information reality and uncertainty not as a set of meanings but rather as a way of storing these meanings in one's mind [10]. More and more often, we can hear voices that school is one of the most conservative institutions of social life, striving for inertia by any means. It responds to changes in the area of new technologies with reluctance, whereas these changes should determine the actions of modern education institutions. Education is a component of the social order-reflecting and co-creating it. This means that school responds to the social changes and also generates them in response to the processes taking place in the society and economy. Modern education has exhausted the capacity of the adaptation doctrine which has been used for many centuries of formal teaching. It no longer fits the changing reality contemporary people live in, therefore, it must be replaced with the doctrine of critical and creative education which stimulates innovation, creativity and active, conscious transforming of the world. Implementation of this doctrine may turn education into a tool to help set the directions of the desired changes and identify the means to introduce these changes. Critical and creative education is the expression of the ideas and desires of people who accept democratic social order. It also means introducing also a democratic educational order. If this happens, the needs and desires of the participants of educational processes will be taken into account and the subjectivity of learners will be more respected. Subjectivity is not only one of the key elements of this education doctrine but also an important characteristic of the democratic model of social life. Mirosław J. Szymański [11] notices that at present, schools must use their socialization role and present valuable life patterns and models to the young people more than in the previous decades. Contemporary education should present an offer of attractive, modern and developing teaching. This offer must include the reality of the rapidly changing world, as well as results of globalization and European integration, increasingly fast scientific and technological progress and-in Poland-also the reality of system transformation. In these conditions, the model of the school needs to change.

Modern issues of highest concern, related to the uncontrolled globalization, challenges faced by societies all over the world, demands made to social institutions-including schools and teachers working at those schools-have brought about the need to seek effective solutions [12]. Radical changes affecting schools and their environments force a 
new approach to the work of teachers: their competencies, tasks, functions and roles [13] (p. 76). They are usually determined based on the most important factors of social and professional human activity and the established position of schools in the education system. They evolve influenced by civilizational and socio-cultural transformations, national development strategies and expectations of all subjects of education policy. The role of the modern teachers is to provide a reliable description and explanation of the reality, generate universal ideas and values, perform experiments, provide advice and initiate creative activities. They are required to identify the directions of changes happening in the world and explain the phenomena these changes initiate, thus they are expected to act as translators and interpreters of reality. One of the key roles of teachers should be preparing young people to live in the world of the future. Constantly changing school reality where every change is unique forces teachers to improve their competencies and gain new ones all the time. It also poses new challenges and tasks and requires the revival of the teaching ethos, redefinition of values, standards and patterns of behavior and restoration of the teacher-student relationship where the teacher is a master and guide in a world of knowledge, values and life, who organizes ideas, corrects errors, dissolves doubts and points to what is important. One of the most important challenges modern teachers face is supporting students in acquisition and development of creativity [1,14-18].

This paper consists of five sections. Save the introduction, we included some terminology arrangements in the second part of the text. Section 3 presents the methodology strategy we adopted in our study. In the fourth part, we present the results of a study into the didactic methods and forms identified by teachers to develop creativity among students aged 14-20. The fifth part includes discussion, which refers also to the research conducted by other specialists, and conclusions.

\section{The Need to Develop Creativity-As a Key Competence for Sustainability-In Modern Teaching-Learning Processes}

Creativity is an essential attribute of human life today and in the future. It is also considered as one of the most important-a key competence for sustainability. Without this competence, it is believed that the sustainable development paradigm may not be feasible. Creativity allows someone, for example, to search for ways of sustainable management of natural resources [19], alternative conflict resolutions and new business solutions and effectively use new technologies, etc.

In Maslow's self-actualization theory of human creativity, creativity is widely considered as a self-actualizing process, fulfilling human basic needs [20]. The creative process will bring about optimal happiness (named as "flow" experience) and long-lasting intrinsic motivation to creators [21]. It is an extremely valuable characteristic and not only from the individual point of view. Creative thinking is "presenting something new" and also

- creating structures-by recognizing differences;

- creating relationships-by recognizing similarities;

- creating procedures-by recognizing changes;

- $\quad$ recognizing and changing levels;

- $\quad$ recognizing and transforming points of view.

Creativity is often defined as the exploring, imagining and creative thinking processes which occur based on one's knowledge, motivation, emotion and experiences that lead to creating new, useful and valuable products (ideas, solutions or specific things) [22-24]. As Tran, Ho, Mackenzie and Le [4] (pp. 11-12) conclude, in such processes, curiosity-driven people conduct an exploration to identify problems and observe and ask questions to find out how other people have created new things. Imagination consists of both creative and re-creative elements. Creative imagination refers to designing things in new ways or making connections to form new images. Re-creative imagination helps recall and re-envision prior images. Creative thinking is then the ability to generate new ideas or solutions and select unique or the most useful idea or solution to develop or apply in action. Curiosity, imagination and creative thinking are considered core processes of creativity. 
As Glăveanu [1] stressed, Kaufman and Beghetto [25] famously distinguished between four types of creativity: mini-c (the creativity involved in learning and meaning-making), little-c (the creativity of mundane, everyday activities), Pro-C (the creativity involved in professional activities) and Big-C (the revolutionary creativity that transforms culture and society). In this model, creativity contributes to our individual and collective lives in different ways. It helps us learn and improvise in our daily interactions, it helps us innovate at work and, in some cases, generate products that get to be recognized by entire communities, nations or at a global level. In each instance, creativity is seen as something good, something people have or can cultivate, something that generates progress.

Creativity may be viewed as understanding and application of the skills we posses. It involves questioning of what has already been said, discussing and interpreting. In an educational sense, creativity should refer to human behaviors and attributes. In this meaning, creativity may be a synonym of creative attitude as a constant life disposition which shows itself in different behaviors of an innovator and refers to the personological dimension of creativity. A creative person is sensitive towards the world and thinks fluently and independently. They are capable of creative thinking, transforming things and have an analytical and synthetic mind. They can think independently, notice ambiguities, are flexible, optimistic and believe in themselves. A creative person is not afraid to take risks, is open to new experiences and is highly disciplined and persistent. Today, creativity is a determinant of success in reaching goals and completing tasks in the external world and in terms of self-improvement.

Creativity enables active participation in the world of changes. It is commonly believed that creativity will allow people to solve the complex future problems which are impossible to foresee today. With innovative thinking, today's students-future active citizens-will be able to change the reality It is worth emphasizing that education plays a central role in the development of human innovation skills [26].

Innovation should be a new, or partially new, thing that is created using a systematic approach and then improved by doing research, and it has not appeared in a daily working system [27]. Innovation is differently understood in many fields of social practice and science. In the context of innovation as a process, innovations are the last stage of the cycle of change introduction, implementation, application and integration, that is, the process of internalization of change.

The school of the future must adapt more and more to the dynamically changing world and developing post-industrial society. In order to survive in the conditions of the future, learning must differ from the hitherto dominating transmission-based education. If one of the objectives of modern education is to prepare students to live in the changing world, then it is necessary to teach them creative thinking and prepare them to introduce creative and innovative solutions for the complex problems they will face in the future. In recent years, scholars and educators alike have stressed the importance of preparing students for a future that will demand complex problem solving and creative thinking [28]. The type of thinking and working that will be needed is not the industrial behaviors and skills that the present school system was designed for and still promotes [29]. Ken Robinson [30] stressed that the very future of civilization hinges upon the creative capabilities of young people and one of the most important things we can do in schools is to foster creativity. With this need to support student creativity, there is a need to assess how learning environments can help educators achieve this goal [31]. It is worth stressing that experience of engaging in creative activities or creativity training was found to have positive impacts on working effects, learning motivation, confidence, self-concept, resilience, subjective well-being and the positive psychology of learners [32-34].

In order to meet the challenges of postmodern reality, living in a world of constant changes, for more than 50 years (U Thant's report, which was one of the first contained a list of threats significant for all mankind and called for cooperation in solving them by the entire international community, was published in 1969) experts were looking for a new model of development. The needs of the global society seem to meet the model of 
sustainable development, which ensures the survival of the human species and the planet Earth.

According to the paradigm of sustainable development, indivuduals must acquire specific competences-those that are related to the profession and also related to the development of critical citizenship [19]. Experts call those competences "the 4 C's: Communication, collaboration, critical thinking, and creativity" [19] (p. 7).

Vivian M. Y. Cheng noticed that in the modern paradigm of sustainability, the role of creativity is of growing significance [34]. In 2000, „Future Forum” Organisation for Economic Cooperation and Development (OECD) published an influential document titled The Creative Society of the 21st Century. The concept of the "creative society" did not refer to the widely extended culture or "art" sector. New ways of configuration of technology, economy, society and government were discussed. In 2005, The United Nations Conference on Trade and Development (UNCTAD) made "Creative Economy" the main pillar of its development policy, and its "Creative Economy Report" from 2008 (and another one from 2010) provided impressive details regarding the use of art and creative industries in regular and systemic development. It is worth noticing that for years, all the most important classifications of the key competencies for sustainable development have been listing creativity as one of the main (base) and critical key competencies (see [35-39]). Clemente [40] notes that sustainability and creativity have always appeared in urban design in a synergizing relationship. Iannarone [41] suggests that we should cultivate creativity and wisdom in practice and in theory as well so as to plan for sustainability. For Albrechts [42], creativity is a force to drive the society toward sustainability through its capacity of imagining and envisioning.

It seems that such a significant role in creating the sustainable order results from the fact that creativity is an extremely open-ended concept which enables an innovative approach to changing the unsustainable life model, solving new, complex problems with creative, "out of the box" thinking which leads to innovations. Creativity can mean anything from humanity's ability to transform themselves and the world to the fairly mundane notion of 'problem solving'. In addition, creativity is of great importance in supporting entrepreneurship, building skills, improving wellbeing, facilitating freedom of speech and dialogue and ensuring significant growth in economy and employment. As noticed by Laužikas and Mokšeckienè, creativity for sustainable development allows the following actions to be implemented: investments in human resources, training activities, research, lifelong learning and entrepreneurship. They, in turn, open new opportunities to combine arts and business/economy and to gather a wide portfolio of artistic and business talents in one area (art incubators and/or clusters) where art and business complement each other [43]. It is worth pointing out that creative competencies are the key elements of the whole system of innovations in post-industrial societies.

Creative thinking is crucial in achieving the United Nation's Sustainable Development Goals (SDGs) [44]. Creative competencies enable actions to solve new, complex problems in all areas of sustainable development. Creativity boosts environmental, social and economic performance by enabling the development of green products and processes. Creative thinking has become an important tool driving green innovation within organizations and plays a critical role in enhancing sustainability performance [44].

As noticed by A. Joffe [45], creativity in sustainable development refers to its three critical dimensions: human development (artistic and creative self-expression, self-esteem enhancement, emotional and intellectual stimulation, confidence building, etc.), social development (community participation, youth and gender involvement, contribution to democracy, social inclusion, social cohesion, the building of social capital, etc.) and economic development (income generation, poverty alleviation, employment (jobs), small business development, foreign exchange earnings, investment, city development and regeneration).

The International Center for Creativity and Sustainable Development at UNESCO points out that creativity competence may be used 
- $\quad$ to achieve sustainable consumption and production;

- $\quad$ to bring new vitality to urban cities;

- to alleviate poverty and improve livelihoods, employment and economic growth,

- $\quad$ to protect environment and environmental resources;

- to protect cultural heritage and promote cultural exchange;

- $\quad$ to design public facilities and to improve public wellness;

- $\quad$ to design sustainable products.

In addition, creativity supports intercultural dialogue led both within and between the societies and facilitates the development of the "good" of a bigger community—rather than its opposite, exclusion or conflict, which are clearly "bad" development. Creativity enables the use of traditional knowledge for better management of natural resources and ecosystems and supports nurturing and/or designing the environment built to improve our wellbeing and our sense of place.

In the context of sustainable development, cultural expression is also important. The evolution of mankind reveals that cycles of economic prosperity and technical inventiveness in societies often coincide with the renewal of artistic and cultural expressions. This means that creative culture is neither an obstacle nor a secondary component of development, but its engine. Development is not only about growth, it is also about access to satisfactory intellectual and spiritual existence; it is not only about "having more", but also about "feeling better". Creativity is necessary to create works of art and, in a wider context, the material culture. It is also worth emphasizing that through culture one can promote concepts critical for sustainable development such as social justice, gender equality, fair trade or environmental protection. Art is a carrier of values, and because of its wide audience, it may become the promotor of the necessary changes.

In the context of sustainable social and economic development, creativity is the competence which has enabled survival of businesses during the crisis caused by the coronavirus pandemic. A creative approach has facilitated the development of smaller and bigger businesses, cultural activities and initiatives to prevent exclusion in these difficult times. Creativity supports business and, in a wider context, economic development at many levels [46]. Thomas Empson, Shannon Chance and Shushma Patel suggest the following question should be posed: 'Can we sustain our current occupation of Earth using current practices?'. Their answer is definite: 'No, we cannot' [46]. Thus, creative competencies may help to find a solution in this critical situation. Thanks to non-standard, creative approaches, the existing, impossible-to-keep development model must be replaced with a new one that is sustainable, planet-friendly, just and more efficient. To achieve long-term sustainability, we must strive for a green economy and come up with solutions to address limitations to resource footprints. This will require innovations across the board and creativity in all fields. Creativity and sustainability are closely linked. The world must resort to the ultimate renewable resource: human ingenuity and creativity.

Creativity is at the heart of sustainability, rooted in sustainable social, economic, environmental and cultural practices. It is a special kind of renewable resource and human talent [47]. According to Paletz and co-workers, reusing and recycling are closely related to adaptive creativity and novelty [48]. To sum up, the literature informs us that human creativity may be closely connected with education for sustainability practices at both individual and societal levels.

The reflections above indicate that in order to fulfill the sustainable development goals, students must learn to associate creativity with sustainability. Helping them understand sustainability by exposing them to the SDGs and designing new creations that honor the planetary boundaries is crucial. The first step is teachers supporting their students in acquiring and developing creative competencies. They can do this using adequate teaching strategies and choosing the right didactic methods and forms. 


\section{Methodological Assumptions of Research}

\subsection{Main Goal of the Research and the Research Method}

The research employed the quantitative paradigm, because we wanted to have as broad a picture as possible of how teachers in our region develop creativity in their students. Moreover, the choice of the quantitative paradigm made it possible to achieve the exploratory goal of the research. The method we used was the survey method. Survey allows a large amount of data to be collected in a fairly short time [31], which in turn allowed us to create the broadest possible picture of how teachers develop students' creativity in the region of interest to us. Since the questionnaire is a method of obtaining data ensuring anonymity, the researcher can obtain honest answers from the respondents [31].

The objective of the research was to explore and to describe [31] teaching methods and forms used by teachers at the third (junior high school) and the fourth (high school) stages of education in order to support acquisition and development (shaping) of creativity in students.

It was assumed that teaching methods and techniques may play the most important role in shaping students' creativity [14]. A teaching method was defined as a systematically and intentionally used way of working with students to complete the planned educational goals [49,50]. Didactic forms are the organizational aspect of teaching, which unlike teaching methods, involve the way teachers and students work. Teaching forms include the external conditions of teaching [51], thus, they are the set of external personal and material conditions that influence the course and characteristics of the teaching-learning process.

In the Polish education system, the most popular division is classification into four groups of teaching methods:

- methods of instruction (association);

- problem-based learning, including didactic games and activating methods;

- expository methods;

- practical methods.

Teachers use methods of instruction when they want to present a large amount of information to a big group of students quickly - the obvious advantage of instructionbased methods is their cost-effectiveness. The disadvantage of these methods is their low efficiency. Adolescent students are prepared to learn through instruction because they are able to focus for a longer time. Despite this, the effectiveness of instructionbased methods is very low-teenagers do not want to listen to lectures, descriptions or explanations. Unlike instruction, problem-based learning methods do not give students ready information but direct them so they acquire knowledge and skills through solving theoretical and practical problems. During problem-based learning students are active; they search for knowledge themselves. This fosters their development, independence and thinking, as well as gaining and improving competencies. Traditional methods of education determine teaching and learning via the memory processes, and thus, they are reproductive. In today's school where the goal of education is to prepare students for active life in the future world, problem-based learning is of particular importance. The essence of such learning is to direct and guide students as they acquire knowledge rather than provide them with information in a traditional way through lecturing and then evaluate how much of these encyclopedic resources they have remembered. One of the subgroups within the problem-based methods are activating methods, which are of particular demand in modern schools. The activating method concept is based on the postulate of learning through acting, experience and critical reflection of this acting (experience). The essence of learning is the students' activity, and it is expressed in the main didactic principles. The teaching-learning process should stimulate complex activity of students and encourage them to move to higher and higher levels of this activity. Only then will the students be capable of acquiring and developing their competencies, including creativity and innovation.

Expository or validating methods are used to develop attitudes and a system of values and beliefs. Using these methods is connected with experiences and emotions of students. Expository classes should stimulate imagination, emotions and encourage intellectual 
exploration of the work presented. To fulfill their role, the classes cannot be led according to a single recipe or template. This, in turn, requires high methodology and creative competencies from the teachers.

\subsection{Subject of Research and Research Questions}

The subject of the research was the didactic methods and forms chosen by teachers to shape students' creativity. The primary problem was the question: which educational methods and forms do teachers use to shape creativity in their students? To find answers to the research questions, an original survey questionnaire addressed to teachers was developed. It consisted of three parts, and one of them was dedicated to methods and forms used by teachers to develop students' creativity. The questionnaire included 40 didactic methods and 7 educational forms. Teachers had to indicate which methods and forms they use in order to develop creativity and how often they use the methods and forms indicated.

In order to achieve the objective of the research and answer the research question posed, we determined the dependent and independent variables [31]. Based on the analysis of the literature on the subject, we identified the features that may affect the use of specific didactic methods and forms by teachers-the use of specific methods and forms determines the extent to which students acquire creativity competences during school activities. On this basis, dependent and independent variables were identified. For the purposes of this text, the variables listed in Table 1 were considered.

Table 1. Dependent and independent variables. Source: own elaboration.

\begin{tabular}{lll}
\hline Dependent Variables & Independent Variables \\
\hline & - & Subject taught; \\
- Methods identified by the teachers, used to develop & - & Degree of professional promotion; \\
creativity among the students; & - & School level (lower secondary/upper secondary); \\
Forms of teaching identified by the teachers, used to & - & Years of professional experience; \\
develop creativity among the students; & - & Location of schools the respondents work in; \\
& $*$ gender-due to the small number of respondents, it was \\
& considered eventually. \\
\hline
\end{tabular}

Quantitative data obtained from the survey were coded and subjected to statistical analysis using Statistical Package for the Social Sciences (SPSS) software. Depending on the group of data analyzed, the following formulas were used: Pearson Chi-square test, Levene's test, Cramer's V, ANOVA, Bonferroni correction and Games-Howell test. Relations were considered statistically relevant when chi square was $p<0.05$.

\subsection{Sample and Sampling Criteria}

The sample was selected via convenience sampling [52]. The sampling criteria were the availability of the respondents and their consent to participate in the survey. The respondents were informed that their anonymous questionnaires would be coded and the results would be used for scientific purposes. The sample consisted of 337 teachers (see Table 2) of general subjects, working in schools in the Małopolska region (southern Poland). The teachers were employed in lower and upper secondary schools so they worked with students aged 14-20.

Table 2. Teachers' statistical-demographic data. Source: own elaboration.

\begin{tabular}{lll}
\hline \multirow{2}{*}{ gender } & female & 263 \\
\cline { 2 - 3 } & male & 70 \\
\hline \multirow{3}{*}{ school location } & village & 128 \\
\cline { 2 - 3 } & small town & 136 \\
\cline { 2 - 3 } & big city & 73 \\
\hline
\end{tabular}


Table 2. Cont.

\begin{tabular}{|c|c|c|}
\hline \multirow{2}{*}{ school level } & lower secondary school & 177 \\
\hline & upper secondary school & 160 \\
\hline \multirow{5}{*}{ years of employment } & $0-5$ & 36 \\
\hline & $6-10$ & 64 \\
\hline & $11-15$ & 85 \\
\hline & $16-20$ & 102 \\
\hline & 21 and more & 50 \\
\hline \multirow{4}{*}{ degree of professional promotion } & trainee & 14 \\
\hline & contractual teacher & 45 \\
\hline & appointed teacher & 82 \\
\hline & chartered teacher & 196 \\
\hline \multirow{7}{*}{ subject taught } & Polish language & 60 \\
\hline & $\begin{array}{l}\text { human and social sciences (civil knowledge, } \\
\text { history, knowledge about culture, } \\
\text { entrepreneurship) }\end{array}$ & 67 \\
\hline & foreign languages & 74 \\
\hline & Mathematics & 36 \\
\hline & $\begin{array}{l}\text { science and natural sciences (biology, chemistry, } \\
\text { physics, geography, education to family life) }\end{array}$ & 86 \\
\hline & information and technical subjects (ITC, technics) & 9 \\
\hline & arts (music, arts) & 5 \\
\hline
\end{tabular}

\section{Results of the Research}

\subsection{Teaching Methods Used to Develop Creativity in Students by Polish Teachers}

To shape creativity of their students, teachers use methods developing creative thinking and brainstorming (Table 3). The former of the above-mentioned methods is used very often by $30.3 \%$ of the respondents, whereas the latter is used by almost $22 \%$. Next most often used methods were methods of creative problem solving $(11.6 \%)$, drama $(10.7 \%)$ and individual project $(10.1 \%)$. The least popular methods were leading text and diagnostic methods and techniques.

Table 3. Most popular methods used to develop creativity. Source: own elaboration.

\begin{tabular}{lccc}
\hline $\begin{array}{l}\text { Methods Employed to Shape } \\
\text { Students' Creativity }\end{array}$ & Very Often & Sometimes & Occasionally \\
\hline \multicolumn{4}{l}{$\%$} \\
\hline methods of instruction & $\%$ & $\%$ \\
\hline Story & $1.19 \%$ & $0.59 \%$ & $0.59 \%$ \\
\hline Talk & $0.89 \%$ & $0.00 \%$ & $1.78 \%$ \\
\hline Formal lecture & $1.19 \%$ & $1.48 \%$ & $1.19 \%$ \\
\hline Problem-focused lecture & $0.89 \%$ & $0.00 \%$ & $1.48 \%$ \\
\hline Explanation & $2.08 \%$ & $2.08 \%$ & $2.08 \%$ \\
\hline Text work & $1.19 \%$ & $0.30 \%$ & $0.59 \%$ \\
\hline & $3.86 \%$ & $1.78 \%$ & $0.89 \%$ \\
\hline Traditional problem method & problem-based learning methods & $1.78 \%$ \\
\hline
\end{tabular}


Table 3. Cont.

\begin{tabular}{|c|c|c|c|}
\hline $\begin{array}{l}\text { Methods Employed to Shape } \\
\text { Students' Creativity * }\end{array}$ & Very Often & Sometimes & Occasionally \\
\hline & $\%$ & $\%$ & $\%$ \\
\hline Brainstorming & $21.96 \%$ & $5.64 \%$ & $2.37 \%$ \\
\hline Case method & $4.75 \%$ & $5.34 \%$ & $0.89 \%$ \\
\hline Simulation & $4.45 \%$ & $4.15 \%$ & $1.48 \%$ \\
\hline Enactment & $7.72 \%$ & $6.82 \%$ & $1.78 \%$ \\
\hline Curriculum discussion & $7.12 \%$ & $4.15 \%$ & $2.08 \%$ \\
\hline Research method & $4.75 \%$ & $2.37 \%$ & $1.78 \%$ \\
\hline \multicolumn{4}{|c|}{ expository methods } \\
\hline Drama & $10.68 \%$ & $9.20 \%$ & $4.45 \%$ \\
\hline Performing arts & $2.97 \%$ & $2.08 \%$ & $5.64 \%$ \\
\hline Exhibition & $2.37 \%$ & $2.67 \%$ & $3.56 \%$ \\
\hline Display/film & $3.26 \%$ & $4.45 \%$ & $1.19 \%$ \\
\hline \multicolumn{4}{|c|}{ practical methods } \\
\hline Practical classes & $7.42 \%$ & $3.26 \%$ & $1.48 \%$ \\
\hline Laboratory method & $4.45 \%$ & $1.48 \%$ & $2.37 \%$ \\
\hline Measurement & $0.89 \%$ & $0.89 \%$ & $0.30 \%$ \\
\hline Guiding text method & $0.00 \%$ & $30 \%$ & $0.59 \%$ \\
\hline \multicolumn{4}{|c|}{ activating methods } \\
\hline Individual project & $10.09 \%$ & $9.50 \%$ & $4.45 \%$ \\
\hline Group project & $8.61 \%$ & $10.39 \%$ & $5.34 \%$ \\
\hline Integration methods & $0.89 \%$ & $1.78 \%$ & $0.89 \%$ \\
\hline Creative problem solving & $11.57 \%$ & $5.93 \%$ & $3.86 \%$ \\
\hline $\begin{array}{l}\text { Planning methods and } \\
\text { techniques }\end{array}$ & $0.89 \%$ & $2.37 \%$ & $0.59 \%$ \\
\hline Hierarchisation methods & $1.48 \%$ & $1.78 \%$ & $0.59 \%$ \\
\hline Evaluation methods & $0.30 \%$ & $2.08 \%$ & $1.48 \%$ \\
\hline Cooperation-based methods & $1.19 \%$ & $2.97 \%$ & $1.48 \%$ \\
\hline Joint decision-making & $2.67 \%$ & $4.15 \%$ & $1.48 \%$ \\
\hline Creating and defining notions & $5.34 \%$ & $5.93 \%$ & $1.19 \%$ \\
\hline $\begin{array}{l}\text { Diagnostic methods and } \\
\text { techniques }\end{array}$ & $0.00 \%$ & $1.48 \%$ & $1.19 \%$ \\
\hline Creative thinking development & $30.27 \%$ & $8.31 \%$ & $2.08 \%$ \\
\hline Webquest & $1.78 \%$ & $2.67 \%$ & $3.56 \%$ \\
\hline Portfolio/E-portfolio & $2.37 \%$ & $2.37 \%$ & $7.12 \%$ \\
\hline SWOT analysis & $2.08 \%$ & $4.45 \%$ & $1.48 \%$ \\
\hline Mindmap & $5.04 \%$ & $2.97 \%$ & $4.15 \%$ \\
\hline Educational project & $7.12 \%$ & $6.53 \%$ & $8.31 \%$ \\
\hline Metaplan & $2.67 \%$ & $2.37 \%$ & $2.08 \%$ \\
\hline
\end{tabular}

* methods: description, story talk, formal lecture, problem-focused lecture, explanation, text work are methods of instruction; methods: traditional problem method, brainstorming, case method, simulation, enactment, curriculum discussion, research method are problem-based learning methods; methods: drama, performing arts, exhibition, display/film are expository methods; methods: practical classes, laboratory method, measurement, guiding text method are practical methods. The remaining methods belong to the group of activating methods This group is classified as problem-based learning methods. 
Teaching methods used to develop creativity in students differ depending on the subject taught.

In order to develop creativity in their students, teachers of Polish (native) language use mainly problem-based learning and activating methods. Of the respondents, $31.67 \%$ declare they use brainstorming and creative thinking development very often. One fifth of the respondents very often use drama which belongs to the group of expository methods. This method is sometimes employed by $18.33 \%$ of the respondents. A similar percentage of teachers declare they use creative problem solving methods very often (18.33\%). Regarding Polish language teachers, $15 \%$ very often use traditional problem method. Almost $12 \%$ also use didactic games: simulation and staging very often during Polish classes. Staging as a method to stimulate creativity is used sometimes by about $20 \%$ of the respondents. The percentage of teachers who use didactic discussion very often is $11.67 \%$. One in twenty Polish language teachers (5\%) do not develop this competence in their students.

Teachers of other humanities and social sciences subjects (like Polish language teachers) declare that methods they use most often to model creativity are methods developing creative thinking - $28.36 \%$ of the respondents gave that answer. Slightly more than one-fifth of the respondents (21\%) use brainstorming very often as a method to support creativity of students in their third and fourth stage of education. Other methods used very often by this group of teachers are creative problem solving $(13.43 \%)$, individual project $(12 \%)$ and enactment $(12 \%)$.

The methods used very frequently by the foreign language teachers are methods developing creative thinking - almost $40 \%$ of the teachers in this group declared they used it very often. Compared to the Polish language teachers and teachers of other humanities, foreign language educators more often declare they use the group project method to develop creativity among the students of lower- and upper-secondary schools. Almost 15\% of the respondents resort to this method very often. Other popular methods in this group that respondents stated they used very frequently were individual project $(12.16 \%)$, drama $(16.22 \%)$ and brainstorming $(20.27 \%)$.

One quarter of the math teachers model creativity using brainstorming very frequently. Almost $17 \%$ declared they very often used creative problem solving methods. A little more than $10 \%$ of mathematicians stated they very often supported the development of creativity using subject-related exercises. This means that math teachers believe solving mathematical problems may significantly improve creativity. Almost $14 \%$ of the teachers declared that the goals of educational projects they implement is, among others, development of creativity among the students.

As for the natural science and science teachers, slightly more than one quarter declare that in order to develop creativity of their students, they use methods developing creative thinking very often $-14 \%$ of the sciences and natural science teachers use them often and $30 \%$ occasionally. Almost $19 \%$ of the respondents often use brainstorming to stimulate students' creativity. In this group of teachers, the popular methods are: individual projectalmost $12 \%$ of the respondents use it very often and $12 \%$ often, and group project $-12.97 \%$ use it very often and almost $5 \%$ often. In addition, $8.14 \%$ of teachers in this group sometimes use educational project, the aim of which is to develop creativity. Subject-related exercises are used very often by about $12 \%$ of the teachers of natural science and science. A little more than $8 \%$ of the respondents often resort to the research method to develop creativity. Curriculum discussion is used very often by $7 \%$ and often by $5 \%$ of the science and natural science teachers.

Given the variables identified for the purpose of this study, it is worth noticing the relation between using certain methods and the degree of professional promotion of the interviewed teachers (Table 4). 
Table 4. Most popular methods used to develop creativity and degree of professional promotion. Source: own elaboration.

\begin{tabular}{|c|c|c|c|c|}
\hline \multirow{3}{*}{$\begin{array}{l}\text { Methods Employed to } \\
\text { Create Creativity }\end{array}$} & \multicolumn{4}{|c|}{ Level of Professional Promotion of Teachers } \\
\hline & Trainee & Contractual Teacher & Appointed Teacher & Chartered Teacher \\
\hline & $\%$ & $\%$ & $\%$ & $\%$ \\
\hline \multicolumn{5}{|c|}{ methods of instruction } \\
\hline Description & $0.00 \%$ & $0.00 \%$ & $1.22 \%$ & $1.53 \%$ \\
\hline Story & $0.00 \%$ & $0.00 \%$ & $3.66 \%$ & $0.00 \%$ \\
\hline Talk & $0.00 \%$ & $0.00 \%$ & $2.44 \%$ & $1.02 \%$ \\
\hline Formal lecture & $0.00 \%$ & $2.22 \%$ & $1.22 \%$ & $0.51 \%$ \\
\hline Problem-focused lecture & $0.00 \%$ & $2.22 \%$ & $0.00 \%$ & $3.06 \%$ \\
\hline Explanation & $0.00 \%$ & $0.00 \%$ & $3.66 \%$ & $0.51 \%$ \\
\hline Text work & $0.00 \%$ & $2.22 \%$ & $4.88 \%$ & $4.08 \%$ \\
\hline \multicolumn{5}{|c|}{ problem-based learning methods } \\
\hline Traditional problem method & $0.00 \%$ & $2.22 \%$ & $8.54 \%$ & $9.18 \%$ \\
\hline Brainstorming & $15.38 \%$ & $31.11 \%$ & $21.95 \%$ & $20.41 \%$ \\
\hline Case method & $0.00 \%$ & $4.44 \%$ & $2.44 \%$ & $6.12 \%$ \\
\hline Simulation & $7.69 \%$ & $2.22 \%$ & $7.32 \%$ & $3.57 \%$ \\
\hline Enactment & $7.69 \%$ & $11.11 \%$ & $8.54 \%$ & $6.63 \%$ \\
\hline Curriculum discussion & $7.69 \%$ & $6.67 \%$ & $8.54 \%$ & $6.63 \%$ \\
\hline Research method & $7.69 \%$ & $2.22 \%$ & $2.44 \%$ & $6.12 \%$ \\
\hline \multicolumn{5}{|c|}{ expository methods } \\
\hline Drama & $30.77 \%$ & $10.98 \%$ & $8.89 \%$ & $9.69 \%$ \\
\hline Performing arts & $7.69 \%$ & $4.44 \%$ & $3.66 \%$ & $2.04 \%$ \\
\hline Exhibition & $0.00 \%$ & $2.22 \%$ & $1.22 \%$ & $3.06 \%$ \\
\hline Display/film & $0.00 \%$ & $2.22 \%$ & $4.88 \%$ & $3.06 \%$ \\
\hline \multicolumn{5}{|c|}{ practical methods } \\
\hline Practical classes & $7.69 \%$ & $8.89 \%$ & $4.88 \%$ & $8.16 \%$ \\
\hline Laboratory method & $7.69 \%$ & $4.44 \%$ & $2.44 \%$ & $5.10 \%$ \\
\hline Measurement & $0.00 \%$ & $0.00 \%$ & $0.00 \%$ & $1.53 \%$ \\
\hline Guiding text method & $0.00 \%$ & $0.00 \%$ & $0.00 \%$ & $3.06 \%$ \\
\hline \multicolumn{5}{|c|}{ activating methods } \\
\hline Individual project & $7.69 \%$ & $8.89 \%$ & $8.54 \%$ & $11.22 \%$ \\
\hline Group project & $7.69 \%$ & $4.44 \%$ & $7.32 \%$ & $10.20 \%$ \\
\hline Integration methods & $0.00 \%$ & $0.00 \%$ & $1.22 \%$ & $1.02 \%$ \\
\hline Creative problem solving & $15.38 \%$ & $2.22 \%$ & $18.29 \%$ & $10.71 \%$ \\
\hline $\begin{array}{l}\text { Planning methods } \\
\text { and techniques }\end{array}$ & $0.00 \%$ & $0.00 \%$ & $1.22 \%$ & $1.02 \%$ \\
\hline Hierarchisation methods & $7.69 \%$ & $0.00 \%$ & $2.44 \%$ & $1.02 \%$ \\
\hline Evaluation methods & $0.00 \%$ & $0.00 \%$ & $0.00 \%$ & $0.51 \%$ \\
\hline Cooperation-based methods & $0.00 \%$ & $0.00 \%$ & $2.44 \%$ & $1.02 \%$ \\
\hline Joint decision-making & $7.69 \%$ & $0.00 \%$ & $2.44 \%$ & $3.06 \%$ \\
\hline $\begin{array}{l}\text { Creating and } \\
\text { defining notions }\end{array}$ & $0.00 \%$ & $11.11 \%$ & $6.10 \%$ & $4.08 \%$ \\
\hline
\end{tabular}


Table 4. Cont.

\begin{tabular}{|c|c|c|c|c|}
\hline \multirow{3}{*}{$\begin{array}{l}\text { Methods Employed to } \\
\text { Create Creativity }\end{array}$} & \multicolumn{4}{|c|}{ Level of Professional Promotion of Teachers } \\
\hline & Trainee & Contractual Teacher & Appointed Teacher & Chartered Teacher \\
\hline & $\%$ & $\%$ & $\%$ & $\%$ \\
\hline $\begin{array}{l}\text { Diagnostic methods } \\
\text { and techniques }\end{array}$ & $23.08 \%$ & $35.56 \%$ & $34.15 \%$ & $28.06 \%$ \\
\hline Webquest & $7.69 \%$ & $6.67 \%$ & $0.00 \%$ & $0.00 \%$ \\
\hline Portfolio/E-potrfolio & $0.00 \%$ & $4.44 \%$ & $1.22 \%$ & $2.55 \%$ \\
\hline SWOT analysis & $0.00 \%$ & $2.22 \%$ & $0.00 \%$ & $3.06 \%$ \\
\hline Mindmap & $7.69 \%$ & $4.44 \%$ & $3.66 \%$ & $5.61 \%$ \\
\hline Educational project & $15.38 \%$ & $6.67 \%$ & $3.66 \%$ & $8.16 \%$ \\
\hline Metaplan & $15.38 \%$ & $0.00 \%$ & $3.66 \%$ & $2.04 \%$ \\
\hline
\end{tabular}

The analysis of the results implies that drama—as a method to develop creativity in students-is used mainly by the trainee teachers who have just begun their careers. Similarly, only trainees and contractual teachers use the modern teaching method Webquest. Trainees also declared they used methods like metaplan (15.38\%) or educational project $(15.38 \%)$ to develop creativity among their students. Curriculum discussion is used at a similar level. Brainstorming, in turn, is preferred by the teachers with higher degrees of professional promotion (trainees-15.38\%; contractual-31.11\%; appointed-21.95\%; chartered-20.41\%).

\subsection{Didactic Forms Used to Develop Creativity in Students}

The most frequently chosen didactic forms to develop creativity of students are individual work and group work. The former of the above-mentioned forms is used very often by $43.6 \%$ of the respondents, whereas the latter is used by $37.1 \%$. A relatively popular form is also homework, which is used very often by $30 \%$ of the respondents (see Figure 1).

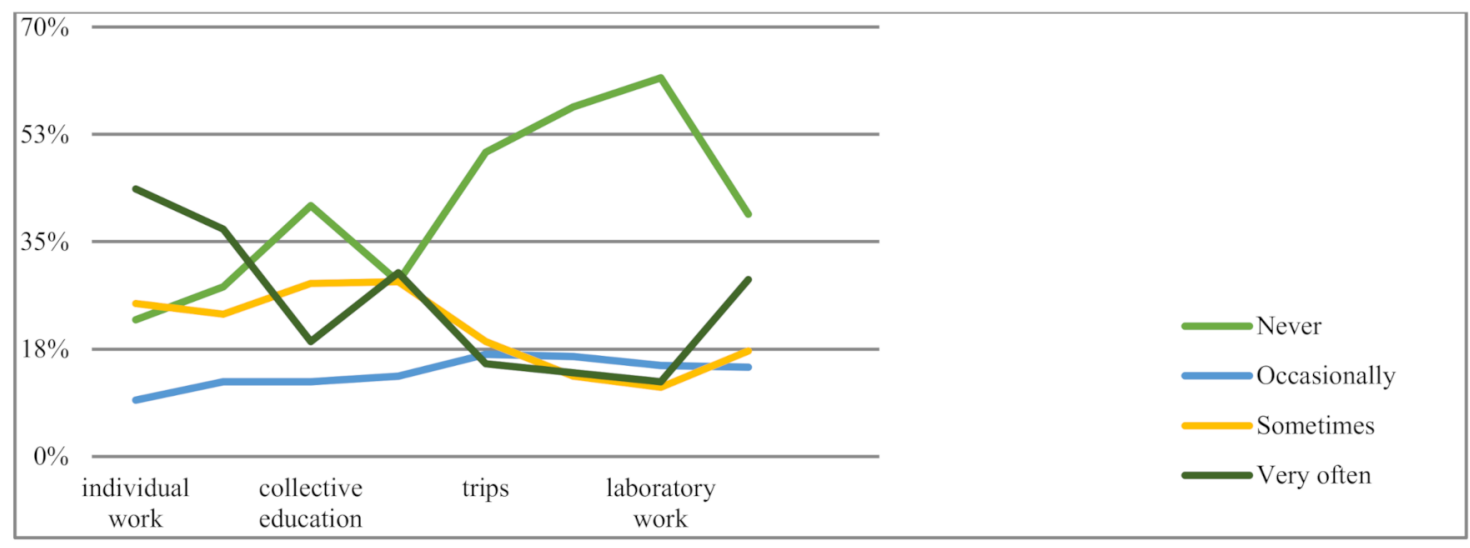

Figure 1. Forms of education most often used to enhance creativity. Source: own elaboration.

The analysis of the results allowed the relationships between the forms of work used to develop this competence and the selected variables to be determined. Group work is most often used by the teachers with more years of professional experience (more than 16 years) and a higher degree of professional promotion (chartered teachers). It is also used more often in the schools located in big cities (Figure 2). 


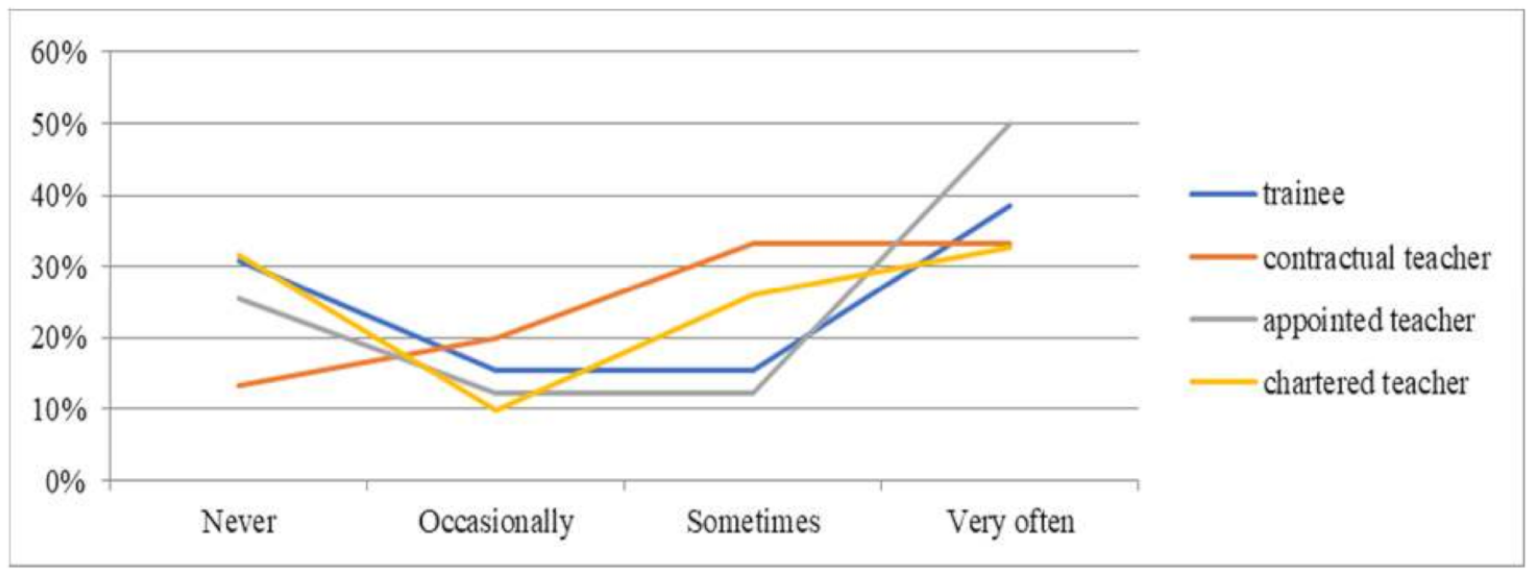

Figure 2. Group work in the development of students' creativity and the stage of teacher promotion. Source: own elaboration.

The use of collective education to develop students' creativity is statistically dependent, similarly to the use of group work, on the stage of education (see Table 5) and school location (see Table 6). This form of developing creativity was indicated more often by teachers at lower secondary schools and rural schools. That means teachers working with younger students more often than teachers in upper secondary schools choose not very effective collective education as a tool for shaping creativity. Thus, younger students may not achieve a high level of creativity competence, because teachers do not stimulate their work during lessons appropriately.

Table 5. Collective education in the development of students' creativity and the stage of education. Source: own elaboration.

\begin{tabular}{lccc}
\hline & \multicolumn{3}{c}{ Educational Stage } \\
\cline { 2 - 4 } & Lower Secondary School & Secondary School & Total \\
\cline { 2 - 4 } & $\%$ & $\%$ & $\%$ \\
\hline Never & $31.07 \%$ & $52.35 \%$ & $40.80 \%$ \\
\hline Occasionally & $10.73 \%$ & $14.09 \%$ & $12.27 \%$ \\
\hline Sometimes & $33.33 \%$ & $22.15 \%$ & $28.22 \%$ \\
\hline Very often & $24.86 \%$ & $11.41 \%$ & $18.71 \%$ \\
\hline
\end{tabular}

Table 6. Collective education in the development of students' creativity and the location of the school. Source: own elaboration.

\begin{tabular}{lcccc}
\hline & \multicolumn{4}{c}{ School Location } \\
\cline { 2 - 5 } & Village & Town & City & Total \\
\cline { 2 - 5 } & $\%$ & $\%$ & $\%$ & $\%$ \\
\hline Never & $32.81 \%$ & $50.00 \%$ & $39.71 \%$ & $41.27 \%$ \\
\hline Occasionally & $10.16 \%$ & $9.56 \%$ & $20.59 \%$ & $12.05 \%$ \\
\hline Sometimes & $31.25 \%$ & $27.94 \%$ & $20.59 \%$ & $27.71 \%$ \\
\hline Very often & $25.78 \%$ & $12.50 \%$ & $19.12 \%$ & $18.98 \%$ \\
\hline
\end{tabular}

When choosing homework for shaping creativity, a statistically relevant variable was subject taught. This form was most often indicated by teachers of the Polish language and foreign languages (Table 7). 
Table 7. Homework in the development of students' creativity and the subject taught. Source: own elaboration.

\begin{tabular}{|c|c|c|c|c|c|c|}
\hline \multicolumn{7}{|c|}{ Subject Taught } \\
\hline & $\begin{array}{c}\text { Polish } \\
\text { Language }\end{array}$ & $\begin{array}{c}\text { Humanities and } \\
\text { Social Sciences }\end{array}$ & $\begin{array}{c}\text { Foreign } \\
\text { Languages }\end{array}$ & Mathematics & $\begin{array}{l}\text { Natural } \\
\text { Sciences }\end{array}$ & Total \\
\hline & $\%$ & $\%$ & $\%$ & $\%$ & $\%$ & $\%$ \\
\hline Never & $16.67 \%$ & $23.88 \%$ & $31.08 \%$ & $25.00 \%$ & $40.70 \%$ & $28.79 \%$ \\
\hline Occasionally & $8.33 \%$ & $7.46 \%$ & $13.51 \%$ & $19.44 \%$ & $16.28 \%$ & $12.69 \%$ \\
\hline Sometimes & $38.33 \%$ & $34.33 \%$ & $21.62 \%$ & $25.00 \%$ & $24.42 \%$ & $28.48 \%$ \\
\hline Very often & $36.67 \%$ & $34.33 \%$ & $33.78 \%$ & $30.56 \%$ & $18.60 \%$ & $30.03 \%$ \\
\hline
\end{tabular}

The stage of education turned out to be another statistically relevant variable in choosing homework. This form was chosen most often by teachers of upper secondary schools (Figure 3).

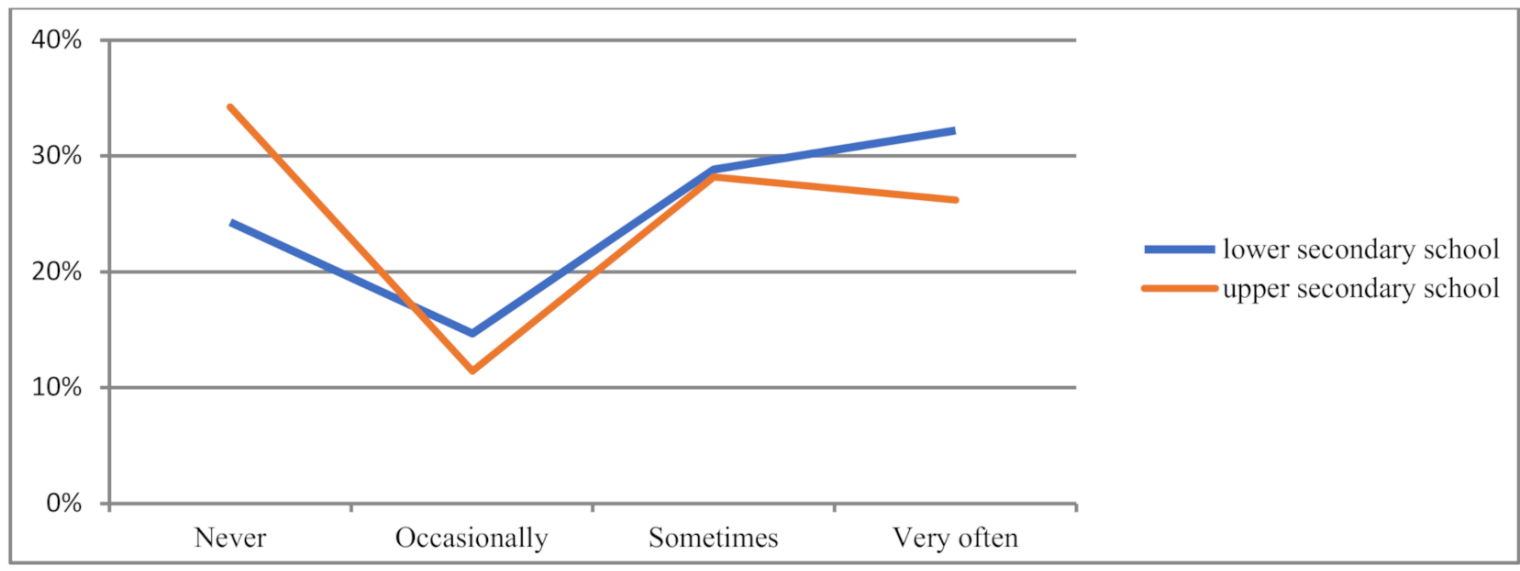

Figure 3. Homework in the development of students' creativity and the educational stage. Source: own elaboration.

The subject taught also influenced the choice of another form of education for developing creativity-laboratory work. This form is most often used by teachers of natural and exact sciences (Table 8).

Table 8. Laboratory work in shaping creativity and the subject taught. Source: own elaboration.

\begin{tabular}{|c|c|c|c|c|c|}
\hline & \multicolumn{5}{|c|}{ Subject Taught } \\
\hline & Polish Language & $\begin{array}{l}\text { Humanities and } \\
\text { Social Sciences }\end{array}$ & $\begin{array}{c}\text { Foreign } \\
\text { Languages }\end{array}$ & Mathematics & Natural Sciences \\
\hline & $\%$ & $\%$ & $\%$ & $\%$ & $\%$ \\
\hline Never & $68.33 \%$ & $62.69 \%$ & $74.32 \%$ & $58.33 \%$ & $48.84 \%$ \\
\hline Occasionally & $18.33 \%$ & $13.43 \%$ & $13.51 \%$ & $2.78 \%$ & $17.44 \%$ \\
\hline Sometimes & $8.33 \%$ & $14.93 \%$ & $5.41 \%$ & $27.78 \%$ & $9.30 \%$ \\
\hline Very often & $5.00 \%$ & $8.96 \%$ & $6.76 \%$ & $11.11 \%$ & $24.42 \%$ \\
\hline
\end{tabular}

In turn, the selection of extracurricular activities as a form of supporting creativity in students was dependent on the stage of education and the location of the school. Most often this form was chosen by lower secondary school teachers (Figure 4) and teachers employed in schools located in large cities (Table 9). 


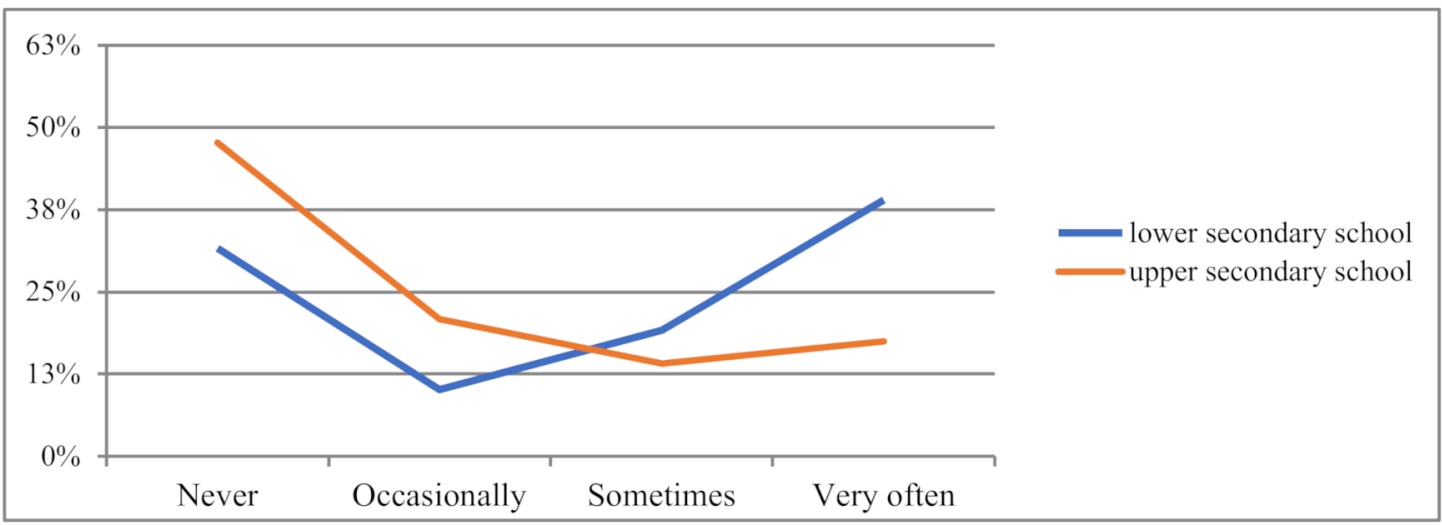

Figure 4. Homework in the development of students' creativity and the educational stage. Source: own elaboration.

Table 9. Homework in the development of students' creativity and the location of the school. Source: own elaboration.

\begin{tabular}{cccc}
\hline & \multicolumn{2}{c}{ Extracurricular Activities-Creativity-Location } \\
& \multicolumn{3}{c}{ Location } \\
\cline { 2 - 4 } & Village & Town & City \\
\cline { 2 - 4 } & \% & \% & $\%$ \\
\hline Never & 29.69 & 44.12 & 51.47 \\
\hline Occasionally & 8.59 & 15.44 & 23.53 \\
\hline Sometimes & 21.09 & 15.44 & 8.82 \\
\hline Very often & 40.63 & 25.00 & 16.18 \\
\hline
\end{tabular}

\section{Discussion and Conclusions}

Creativity is necessary for inventive thinking in any domain and is underappreciated in many formal educational environments. All solution making and construction requires creative thinking. Yet, almost no schools teach for creativity or train teachers to teach for creativity [53]. Thus, teachers must design strategies to support creativity and innovation themselves. They do this, for example, by using activating, problem-based methods of work.

According to the study conducted by Romina Cachia and Anusca Ferrara among 7650 teachers from $27 \mathrm{EU}$ states, educators facilitate creativity of students during developing other competencies and skills such as ability to think (96\%), communication skills $(91 \%)$, ability to learn $(90 \%)$, motivation $(89 \%)$ and curiosity $(86 \%)$ amongst others. The teachers who were more inclined to foster skills and abilities which are related to creativity are younger than 25 years of age (96\%) and have been teaching for less than a year (96\%). Respondents in Luxembourg (100\%), Bulgaria (97\%) and Lithuania (96\%) are more likely to foster skills and abilities related to creativity than respondents in Czech Republic (77\%), Sweden (82\%) and Poland (86\%) [54]. In the context of our study, the most important is the fact that-according to Cachia and Ferrera-Polish teachers do not develop creativity on a daily basis. In terms of activities which take place in the classroom, a great majority of teachers surveyed claimed to encourage learning activities which are likely to allow students to be creative. Developing thinking skills $(83 \%)$, active and participative learning $(80 \%)$ and learning how to learn $(73 \%)$ were the activities mostly rated by teachers. Around two thirds of the respondents also claimed that in their classrooms students were given the opportunity to learn from each other $(62 \%)$ and to work in groups $(60 \%)$. More than eight out of ten respondents ( $86 \%$ ) claimed that the teacher explaining was an activity which often or always took place in class. Only half of the teachers (56\%) surveyed allowed students to learn and discover by themselves. 
In turn, the research by Thapanee Seechaliao implies that in order to develop creativity, teachers and educators should use instructional strategies which include such elements as problems in the beginning, solution findings, testing and evaluation. In addition, using a variety of stimulating ideas to find possible solutions to the problems could facilitate brainstorming and help learners think about new ideas. The results also showed that instructional strategies using questions, classroom discussion, self-directed study, inductive and deductive thinking or media could engage students in learning activities and help them create innovation in learning. Teachers also use teaching by lecturing, which should not be used too often, teaching by demonstrating, teaching by using small group discussion, teaching by using simulations, field trips as a teaching technique, teaching by using induction and teaching by using deduction [55].

It is important for all teachers to understand that creativity is a skill that may be developed in all students. The teacher therefore holds a responsibility to both support and advance the student, thus encouraging and developing a students' natural creativity [56]. All teachers, at every stage of education, should find ways to develop creativity.

Supporting creativity of students has become an unquestionable challenge of 21st century schools. In the global knowledge society where change is the only sure thing, creativity seems to be one of the key competencies enabling individuals to solve the existing and as yet unknown problems. As we know, school as an institution is the place where students should acquire not only knowledge but also competencies. For this reason, the role of the teachers is to support their students as they acquire competencies which will allow them to function today and in the future.

The results of the analysis of the teaching methods and forms used to develop creativity are not optimistic. Out of at least 40 didactic methods, teachers use only a few to develop creativity. One of the most popular methods is brainstorming. However, teachers should remember that in order to be effective, this method has to include certain phases. School practice shows that they simplify this method and focus only on the stage of creating the ideas, while ignoring other stages of the brainstorming process.

Most of the teachers neglect modern teaching methods recommended to develop creativity in students. Not many of them used projects—individual, group and educationalto shape this competency among their students. Projects are commonly considered one of the most effective methods to shape students' competencies. They facilitate independent actions, activity and commitment. Thus, giving up this method means lesser support in developing creativity in students.

Teachers with the least experience (and, consequently, the lowest degree of professional promotion) use the most different methods facilitating creativity, including problembased and modern methods like Webquest or projects. This may be due to better methodology preparation of the younger teachers.

The analysis of the preferred teaching forms indicates that teachers are not always aware that if properly planned and organized, every form of teaching may support the development of creativity among the students. Educators do not use forms like extracurricular classes or trips, or if they do, they do not attempt to facilitate students' creativity. We need more studies to determine why group and individual work are the most often chosen forms of developing creativity in students.

Even though creativity is considered a key competency which is widely discussed in social science, media and postulated as necessary in modern education processes, Polish teachers seem to ignore it and are not committed to developing this competence among their students. Therefore, when preparing prospective teachers (students of teaching specialization) and training those who are already working, a particular emphasis must be put on the necessity to develop this competence at every stage of education.

The method we used in our study has its limitations. Most of all, because we applied convenience sampling, the results of the study cannot be generalized to the entire population of Polish teachers-to obtain results that allow for generalization, a random sampling should be used. 
The use of the survey technique assumes the risk that the questions may be misunderstood by the respondents. We tried to eliminate this risk by conducting pilot studies and consulting on the construction of the questionnaire with teachers.

As we noted, our study was exploratory and descriptive. In subsequent studies, we attempted to answer the question "what is the level of key competences for sustainable development among students?" and we are currently processing the collected data. Another research problem is the issue of the reasons for the selection of specific (most often ineffective) methods that teachers choose to develop students' creativity. Another research problem is the issue of the reasons for the selection of specific (most often ineffective) methods that teachers choose to develop creativity-the qualitative paradigm should be applied in this research, so teachers can have an opportunity to comment on how they develop students' creativity and why they use certain didactic methods and forms.

Author Contributions: Conceptualization, A.M.; methodology, A.M. software, I.O.; validation, A.M. and I.O.; formal analysis, A.M.; investigation, A.M. and I.O.; resources, A.M.; data curation, A.M.; writing —original draft preparation, A.M. and I.O.; writing-review and editing, A.M. and I.O.; visualization, A.M. and I.O.; supervision, A.M. and I.O.; project administration, I.O.; funding acquisition, I.O. All authors have read and agreed to the published version of the manuscript.

Funding: This research received no external funding.

Institutional Review Board Statement: Not applicable.

Informed Consent Statement: Informed consent was obtained from all subjects involved in the study.

Data Availability Statement: The data presented in this study are available on request from the corresponding author.

Conflicts of Interest: The authors declare no conflict of interest.

\section{References}

1. Glăvenau, V.P. Educating which creativity? Think. Skills Creat. 2018, 27, 25-32. [CrossRef]

2. Guilford, J.P.; Fruchter, B. Fundamental Statistics in Psychology and Education, 6th ed.; McGraw-Hill: New York, NY, USA, 1978.

3. Sternberg, R.J.; Lubart, T.I. Defying the Crowd: Cultivating Creativity in a Culture of Conformity; Free Press: New York, NY, USA, 1995.

4. Tran, T.B.L.; Ho, T.; Mackenzie, S.V.; Kim, L.L. Developing assessment criteria of a lesson for creativity to promote teaching for creativity. Think. Skills Creat. 2017, 25, 10-26. [CrossRef]

5. Jónsdóttir, S.R. Narratives of creativity: How eight teachers on four school levels integrate creativity into teaching and learning. Think. Skills Creat. 2017, 24, 127-139. [CrossRef]

6. Heilmann, G.; Korte, W.G. The Role of Creativity and Innovation in School Curricula in the EU27. A Content Analysis of Curricula Documents; European Commission: Luxembourg, 2010. Available online: http://www.pim.com.mt/pubs/JRC_curricula.pdf (accessed on 7 January 2021).

7. Tanaś, M. Primum Non Nocere a Internetowa Przestrzeń Wolności i Aktywności Nastolatków; Nastolatki Wobec Internetu: Warszawa, Poland, 2016.

8. Bauman, Z. The Individualized Society; Polity Press: Cambridge, UK, 2008.

9. Kalimullin, A.M.; Gabdilkhakov, V.F. Tutoring of pedagogical activity and new ideology of teacher training in the higher education institution. Life Sci. J. 2014, 11, 183-187.

10. Klus-Stańska, D. Dokąd Zmierza Polska Szkoła? Wydawnictwo Akademickie ŻAK: Warszawa, Poland, 2008.

11. Szymański, M.J. Funkcje edukacji szkolnej w zmieniającym się społeczeństwie. In Szkoła w Świecie Współczesnym; Muchacka, B., Szymański, M.J., Eds.; Wydawnictwo Nukowe Uniwersytetu Pedagogicznego w Krakowie: Kraków, Poland, 2008.

12. Mróz, A.; Ocetkiewicz, I.; Walotek-Ściańska, K. Which media do polish teachers use to support sustainable development among students? Analysis of research. Sustainability 2018, 10, 1496. [CrossRef]

13. Szempruch, J. Nauczyciel w Warunkach Zmiany Społecznej i Edukacyjnej; Impus: Kraków, Poland, 2012.

14. Hu, W.; Adey, P. A scientific creativity test for secondary school students. Int. J. Sci. Educ. 2010, 24, 389-403. [CrossRef]

15. Csikszentmihalyi, M. Society, Culture, And Person: A Systems View of Creativity. The Systems Model of Creativity; Springer: Dordrecht, The Netherlands, 2014.

16. Crow, B. Changing conceptions of educational creativity: A study of student teachers' experience of musical creativity. Music Educ. Res. 2008, 10, 373-388. [CrossRef]

17. Ivcevic, Z.; Mayer, J.D. Mapping dimensions of creativity in the life-space. Creat. Res. J. 2009, 21, 152-165. [CrossRef]

18. Sydykova, R.; Kakimova, L.; Ospanov, B.; Tobagabylova, A.; Kuletova, U. A conceptual approach to developing the creativity of a music teacher in modern educational conditions. Think. Ski. Creat. 2018, 27, 160-166. [CrossRef] 
19. Zamora-Polo, F.; Sánchez-Martín, J. Teaching for a better world. Sustainability and sustainable development goals in the construction of a change-maker university. Sustainability 2019, 11, 4224. Available online: https://www.mdpi.com/2071-1050/11 /15/4224 (accessed on 7 January 2021). [CrossRef]

20. Maslow, A. Creativity in self-actualizing people. In Toward a Psychology of Being, 2nd ed.; Van Nos/Trand Reinhold Company: New York, NY, USA, 1968; pp. 135-145.

21. Csikszentmihalyi, M. The creative personality. In Creativity: Flow and the Psychology of Discovery and Invention; Harper Collins Publishers: New York, NY, USA, 1996; pp. 51-76.

22. Ferrari, A.; Cachia, R.; Punie, Y. ICT as a driver for creative learning and innovative teaching. In Measuring Creativity; Villalba, E., Ed.; OPOCE: Luxemburg, 2009.

23. Runco, M.A.; Jaeger, G.J. The standard definition of creativity. Creat. Res. J. 2012, 24, 92-96. [CrossRef]

24. Vygotsky, S.L. Imagination and creativity in childhood. J. Russ. East Eur. Psychol. 2004, 42, 7-97. [CrossRef]

25. Kaufman, J.C.; Beghetto, R.A. Beyond big and little: The four C model of creativity. Rev. Gen. Psychol. 2009, 13, 1-12. [CrossRef]

26. Keinäne, M.; Ursin, J.; Nissinen, K. How to measure students' innovation competences in higher education: Evaluation of an assessment tool in authentic learning environments. Stud. Educ. Eval. 2018, 58, 30-36. [CrossRef]

27. Songkhram, N. Creating Innovation: Changed Learners to Innovators; Chulalongkorn University Press: Bangkok, Thailand, 2013.

28. Wagner, T. The Global Achievement Gap: Why Even Our Best Schools Don't Teach the New Survival Skills Our Children Need-And What We Can Do about It; Basic Books: New York, NY, USA, 2010.

29. Richardson, C.; Mishra, P. Learning environments that support student creativity: Developing the SCALE. Think. Skills Creat. 2018, 27, 45-54. [CrossRef]

30. Robinson, K. Out of Our Minds; Capstone Publishing: Sussex, UK, 2011.

31. Babbie, E. The Practice of Social Research; Wadsworth: Belmont, MA, USA, 2013.

32. Amabile, T.; Barsade, S.; Mueller, J.; Staw, B. Affect and creativity at work. Adm. Sci. Q. 2005, 50, 367-403. [CrossRef]

33. Jindal-Snape, D.; Davies, D.; Collier, C.; Howe, A.; Digby, R.; Hay, P. The Impact of creative learning environments on learners: A systematic literature review. Improv. Sch. 2013, 16, 21-31. [CrossRef]

34. Cheng, V.M.Y. Views on creativity, environmental sustainability and their integrated development. Creat. Educ. 2018, 9, 719-743. [CrossRef]

35. de Haan, G. The development of ESD-related competencies in supportive institutional frameworks. Int. Rev. Educ. 2010, 56, 315-328. [CrossRef]

36. De Haan, G. Guide Education for Sustainable Development at Secondary Level. Justifications, Competences, Learning Opportunities. Compiled by the Transfer-21 Programme's "Quality and Com- Petences" Working Group. Available online: http:/ /www.transfer-21 .de/daten/materialien/Orientierungshilfe/Guide_competences_engl_online.pdf (accessed on 28 August 2020).

37. Rieckmann, M. Future-oriented higher education: Which key competencies should be fostered through university teaching and learning? Futures 2010, 44, 127-135. [CrossRef]

38. Rieckmann, M. Key Competencies for a Sustainable Development of the World Society. Results of a Delphi Study in Europe and Latin America; GAIA-Ecological Perspectives for Science and Society: Munich, Germany, 2011; Volume 20, pp. 48-56.

39. Barth, M.; Godemann, J.; Rieckmann, M.; Stoltenberg, U. Developing Key Competencies for Sustainable Development in Higher Education. Int. J. Sustain. High. Educ. 2007, 8, 416-430. [CrossRef]

40. Clemente, M. De-globalization and creativity: A contribution towards sustainable and intercultural architectures and cities. Int. J. Sustain. Dev. 2009, 12, 116-123. [CrossRef]

41. Iannarone, S.S. Planning for Sustainability: Cultivating Wisdom and Creativity in Practice and Theory. 2008. Available online: http:/ / citeseerx.ist.psu.edu/viewdoc/download?doi=10.1.1.487.9576\&rep=rep1\&type=pdf (accessed on 7 January 2021).

42. Albrechts, L. How to enhance creativity, diversity and sustainability in spatial planning: Strategic planning revisited. Urban Landsc. Perspect. 2010, 9, 3-25. [CrossRef]

43. Laužikas, M.; Mokšeckienè, R. The role of creativity in sustainable business. Entrep. Sustain. Cent. 2013, 1, 10-22.

44. Awan, U.; Sroufe, R.; Kraslawski, A. Creativity enables sustainable development: Supplier engagement as a boundary condition for the positive effect on green innovation. J. Clean. Prod. 2019, 226, 172-185. [CrossRef]

45. Joffe, A. The Cultural and Creative Economy in Africa: Challenges and Innovations; Papers commissioned by UNESCO for the preparation of the Creative Economy Report; UNESCO: Beirut, Lebano, 2013.

46. Empson, T.; Chance, S.; Patel, S. A critical analysis of 'creativity' in sustainable production and design. In Proceedings of the 21st International Conference on Engineering and Product Design Education (E\&PDE 2019), Glasgow, UK, 12-13 September 2019.

47. d'Orville, H. The relationship between sustainability and creativity. Cadmus 2019, 4, 65-73.

48. Paletz, S.; Kim, K.; Schunn, C.; Tollinger, I.; Vera, A. Reuse and recycle: The development of adaptive expertise, routine expertise, and novelty in a large research team. Appl. Cogn. Psychol. 2013, 27, 415-428. [CrossRef]

49. Petrina, S. Advance Teaching Methods for the Technology Classroom; Information Science Publishing: Hershey, PA, USA, 2007.

50. Westwood, P. What Teachers Need to Know about Teaching Methods; ACER Press: Budapest, Hungary, 2008.

51. Okoń, W. Nowy Stownik Pedagogiczny; Wydawnictwo Akademickie Żak: Warszawa, Poland, 2001.

52. Christensen, B.; Johnson, L. Educational Research: Quantitative, Qualitative, and Mixed Approaches, 4th ed.; SAGE Publications: Thousand Oaks, CA, USA, 2012.

53. Kaplan, D.E. Creativity in education: Teaching for creativity development. Psychology 2019, 10, 140-147. [CrossRef] 
54. Ferrari, A.; Cachia, C. Creativity in Schools: A Survey of Teachers in Europe; Publications Office of the European Union: Luxembourg, 2010.

55. Seechaliao, T. Instructional strategies to support creativity and innovation in education. J. Educ. Learn. 2017, 6, 4. [CrossRef]

56. Robson, S.; Moseley, D. An integrated framework for thinking about learning. Gift. Educ. Int. 2005, 20, 36-50. [CrossRef] 